\title{
Eag1 Gene and Protein Expression in Human Retinoblastoma Tumors and Its Regulation by $\mathrm{pRb}$ in HeLa Cells
}

\author{
María de Guadalupe Chávez-López ${ }^{1}$, Violeta Zúñiga-García ${ }^{1}$, Blanca Elena Castro-Magdonel ${ }^{1,2}$, \\ Eunice Vera ${ }^{1}$, Efraín Garrido ${ }^{3}$, Janet Sánchez-Ramos ${ }^{3}$, M. Verónica Ponce-Castañeda ${ }^{2}$, \\ M. de Lourdes Cabrera-Muñoz ${ }^{4}$, Yesenia Escobar ${ }^{5}$, Cindy Sharon Ortiz ${ }^{6}$, \\ Elisabeth Hernández-Gallegos ${ }^{1}$, Arturo Avalos-Fuentes ${ }^{7}$ and Javier Camacho ${ }^{1, * \mathbb{C}}$ \\ 1 Department of Pharmacology, Centro de Investigación y de Estudios Avanzados del I.P.N., \\ Mexico City 07360, Mexico; gchavez@cinvestav.mx (M.d.G.C.-L.); vzuniga@cinvestav.mx (V.Z.-G.); \\ blanqfb@yahoo.com.mx (B.E.C.-M.); evera@cinvestav.mx (E.V.); lishergallegos@yahoo.com (E.H.-G.) \\ 2 Hospital de Pediatría, Unidad de Investigación Médica en Enfermedades Infecciosas, CMN SXXI, IMSS, \\ Mexico City 06720, Mexico; vponce@ifc.unam.mx \\ 3 Department of Genetics and Molecular Biology, Centro de Investigación y de Estudios Avanzados del I.P.N., \\ Mexico City 07360, Mexico; egarrido@cinvestav.mx (E.G.); janetbiologia@gmail.com (J.S.-R.) \\ 4 Department of Pathology, Hospital Infantil de México Federico Gómez, Secretaría de Salud, \\ Mexico City 06720, Mexico; dra.cabreramalu@gmail.com \\ 5 Centro de Investigación Clínica Acelerada SC, Mexico City 07020, Mexico; yescobar@cicasite.com \\ 6 Departamento de Radioterapia, Hospital Regional de Alta Especialidad del Bajío, Gto., León 37660, Mexico; \\ drasharonortiz@gmail.com \\ 7 Department of Physiology, Biophysics and Neuroscience, Centro de Investigación y de Estudios Avanzados \\ del I.P.N., Mexico City 07360, Mexico; javalos@cinvestav.mx \\ * Correspondence: fcamacho@cinvestav.mx
}

Received: 10 December 2019; Accepted: 18 January 2020; Published: 21 January 2020

\begin{abstract}
Retinoblastoma is the most common pediatric intraocular malignant tumor. Unfortunately, low cure rates and low life expectancy are observed in low-income countries. Thus, alternative therapies are needed for patients who do not respond to current treatments or those with advanced cases of the disease. Ether à-go-go-1 (Eag1) is a voltage-gated potassium channel involved in cancer. Eag1 expression is upregulated by the human papilloma virus (HPV) oncogene E7, suggesting that retinoblastoma protein $(\mathrm{pRb})$ may regulate Eag1. Astemizole is an antihistamine that is suggested to be repurposed for cancer treatment; it targets proteins implicated in cancer, including histamine receptors, ATP binding cassette transporters, and Eag channels. Here, we investigated Eag1 regulation using $\mathrm{pRb}$ and Eag1 expression in human retinoblastoma. The effect of astemizole on the cell proliferation of primary human retinoblastoma cultures was also studied. HeLa cervical cancer cells (HPV-positive and expressing Eag1) were transfected with RB1. Eag1 mRNA expression was studied using qPCR, and protein expression was assessed using western blotting and immunochemistry. Cell proliferation was evaluated with an MTT (3-(4,5-dimethylthiazol-2-yl)-2,5-diphenyltetrazolium bromide) assay. RB1 transfection down-regulated Eag1 mRNA and protein expression. The human retinoblastoma samples displayed heterogeneous Eag1 mRNA and protein expression. Astemizole decreased cell proliferation in primary retinoblastoma cultures. Our results suggest that Eag1 mRNA and protein expression was regulated by $\mathrm{pRb}$ in vitro, and that human retinoblastoma tissues had heterogeneous Eag1 mRNA and protein expression. Furthermore, our results propose that the multitarget drug astemizole may have clinical relevance in patients with retinoblastoma, for instance, in those who do not respond to current treatments.
\end{abstract}

Keywords: Eag1 channels; retinoblastoma; astemizole; tumor suppressor; potassium channels; Kv10.1; KCNH1 


\section{Introduction}

Retinoblastoma is the principal pediatric intraocular malignant tumor [1]. Unfortunately, enucleation of either one or both eyes is commonly performed. Despite this, the overall survival in developed countries is very high, but low cure rates and low life expectancy are observed in low-income countries [2]. Therefore, alternative therapeutic approaches to treat these patients in low-income countries are needed. Patients who had a bilateral retinoblastoma in childhood have an elevated risk to develop other tumors [3,4]. However, why many other tissues seem not to be affected by the RB1 mutations remains elusive. The retinoblastoma gene (RB1) was the first tumor suppressor to be described [5]. The corresponding encoded $\mathrm{Rb}$ protein $(\mathrm{pRb})$ binds to several proteins including different transcription factors like E2F, snRNA-activating protein complex (SNAPc), TATA-binding protein (TBP), and Brahma-related gene (BRG) [6,7]. In addition, pRb regulates many epigenetic processes and has been suggested to be required to maintain chromosomal stability [8]. Accordingly, $\mathrm{pRb}$ has a very important role in cell proliferation, differentiation, and apoptosis, both in normal cells and different cancers [9]. Interestingly, retinoblastoma samples share a common miRNA expression profile, and some mRNA targets of these miRNAs include RB1, as well as other tumor suppressor genes [10].

Ether à-go-go-1 (Eag1, KCNH1, Kv10.1) is a voltage-gated potassium channel displaying oncogenic properties [11]. Eag1 has a very restricted distribution in healthy tissues, and it is mainly expressed in the brain; slightly in the placenta, testes, adrenal glands; and transiently in myoblasts $[12,13]$. Eag channels have also been detected in the normal retina [13,14]. In contrast, Eag1 is overexpressed in many cancer cell lines and human tumors, including those from the liver, cervix, lung, breast, and colon [11,13,15-19]. Interestingly, the human Eag-related channel (Herg1), which is very relevant for cardiac repolarization [20], has been found to be overexpressed in retinoblastoma samples from patients that did not benefit from conservative treatment, namely chemotherapy followed by cryotherapy and/or laser treatment [21]. Eag1 has also been proposed as a novel anti-cancer target because the inhibition of either its gene expression or channel activity decreases the tumor cell proliferation in vitro and in vivo [22]. The second-generation anti-histamine astemizole is a very interesting molecule to be repositioned for cancer therapy because it targets different proteins involved in cancer, including histamine receptors and ATP binding cassette (ABC) transporters, as well as Eag1 and Herg channels [22-25].

Eag1 mRNA expression was detected by our group in cervical biopsies from patients with human papilloma virus (HPV) infections [16]. Later, we also discovered that normal human keratinocytes do not express Eag1 mRNA, but a very high Eag1 expression was found when these cells were transfected with the HPV oncogenes E6 and/or E7 [26]. These observations led us to suggest that Eag1 expression may be regulated by the p53 and Rb pathways, especially because the E7 HPV oncoprotein targets and inactivates $\mathrm{pRb}[9]$. Actually, it has been reported that the p53-miR-34 pathway and E2F (one of the transcription factors targeted by $\mathrm{pRb}$ ) regulate Eag1 expression $[27,28]$. Herein, we investigated the regulation of Eag1 by RB1 in HeLa cervical cancer cells because these cells are HPV-positive, express both Eag1 channels and RB1 [11,26], and are very suitable for transfection. In addition, we studied Eag1 expression in human retinoblastoma samples, as well as the effect of astemizole on the cell proliferation of human retinoblastoma primary cultures.

\section{Materials and Methods}

\subsection{Cell Line and Reagents}

The HeLa human cervical cancer cell line was obtained from the American Type Culture Collection (Manassas, VA, USA) and cultured in Dulbecco's modified Eagle's medium (DMEM) (Invitrogen, Carlsbad, CA, USA), supplemented with $10 \% \mathrm{FBS}$, and incubated at $37^{\circ} \mathrm{C}$ in a $5 \% \mathrm{CO}_{2}$ atmosphere. 
Astemizole was kindly provided by Liomont Laboratories (Mexico City, Mexico). Imipramine and DMSO were purchased from Sigma Chemical Co. (St. Louis, MO, USA). The anti-Eag1 antibody was purchased from Novus Biologicals, (Centennial, CO, USA), the anti-Rb antibody was purchased from Santa Cruz Biotechnology (Dallas, TX, USA), and the anti-actin antibody was purchased from Sigma Chemical Co. (St. Louis, MO, USA).

\subsection{Cell Transfection}

HeLa cells were transfected using Lipofectamine 2000 (Invitrogen, Carlsbad, CA, USA) following the manufacturer's protocol. Briefly, $2 \mu \mathrm{g}$ of the PCMV-RB1 plasmid (a generous gift of Dr. Roberto Weinmann) in $100 \mu \mathrm{L}$ Opti-MEM medium (Invitrogen, Carlsbad, CA, USA) were mixed with $5 \mu \mathrm{L}$ Lipofectamine 2000 and incubated for $45 \mathrm{~min}$ at room temperature. The transfection mixture was then combined with $2 \mathrm{~mL}$ fresh medium $\left(37^{\circ} \mathrm{C}\right)$ and added to the cells. After an incubation period of $5 \mathrm{~h}$, the transfection mixture was removed, cells were washed twice with PBS, and fresh medium was added; the incubation continued for $48 \mathrm{~h}$. Control experiments were performed under the same conditions, but the cells were transfected with the empty vector (pcDNA3).

\subsection{Human Tumor Samples and Primary Cultures}

Retinoblastoma samples were obtained from 40 enucleated eyes from patients attending the Hospital de Pediatría CMN SXXI, Instituto Mexicano del Seguro Social (IMSS), and the Hospital Infantil de México "Federico Gómez", and participating in a larger IRB approved case-series study [29]. The age of the children was $19.75 \pm 14.7$ months (range 2 to 60 months); twenty-four samples were obtained from girls and sixteen tissues from boys. All patient parents gave their informed consent for inclusion before the patients participated in the study. The study was conducted in accordance with the Declaration of Helsinki, and the protocol was approved by the Ethics Committee of the Hospital Infantil de México "Federico Gómez" (Children's Hospital of Mexico "Federico Gómez") (project identification code: HIM/2012/54 SSA 1042), and the Comisión Nacional de Investigación Científica (National Commission for Scientific Research), IMSS (project identification code: IMSS R2012-785-039). The children had not received any anticancer treatment. Tumors were collected and cultured in sterile conditions for a week in FBS 10\% RPMI (Gibco ${ }^{\circledR}$, Thermo Fisher Scientific, Waltham, MA, USA) medium. Thirty retinoblastoma primary cultures (15 unilateral and 15 bilateral) were used to obtain RNA. Samples intended for immunohistochemistry were fixed in paraformaldehyde. Ten retinoblastoma primary cultures (five unilateral and five bilateral) were used for cell proliferation assays. The primary cultures were used only once with no passages. A human pediatric normal brain obtained postmortem was used as a "control" for RNA expression studies.

\subsection{Real-Time PCR}

Total RNA was extracted with TRIzol reagent. Two micrograms of total RNA was reverse-transcribed using Moloney Murine Leukemia Virus Reverse Transcriptase (M-MuLV, M0253S, BioLab®, Inc., Lawrenceville, GA, USA). Real-time PCR was performed with $1 \mu \mathrm{L}$ of cDNA using the TaqMan $^{\mathrm{TM}}$ detection system (Applied Biosystem, Foster City, CA, USA) and the Universal PCR Master Mix reagents kit (Thermo Fisher Scientific, Waltham, MA, USA). KCNH1 TaqMan probes for Eag1 (ID: Hs00924320_m1) and h-HPRT (hypoxanthine-guanine phosphoribosyl transferase, Part Number $4326321 \mathrm{E}$, constitutive gene) were used. The PCR protocol was $95^{\circ} \mathrm{C}$ for $15 \mathrm{~s}$ and $60{ }^{\circ} \mathrm{C}$ for $1 \mathrm{~min}$ (40 cycles). The data were analyzed using the $2^{-\Delta \Delta \mathrm{Ct}}$ method.

\subsection{Cell Proliferation}

Cell proliferation was assayed using the colorimetric method with a 3-(4,5-dimethylthiazol-2 -yl)-2,5-diphenyltetrazolium bromide (MTT) cell proliferation kit I (Boehringer Mannheim GmbH), as previously described [26]. Briefly, the cells were incubated for $96 \mathrm{~h}$ in culture medium either alone or in the presence of astemizole $(2 \mu \mathrm{mol} / \mathrm{L}, 5 \mu \mathrm{mol} / \mathrm{L}$, or $10 \mu \mathrm{mol} / \mathrm{L})($ kindly provided by Liomont 
Laboratories, Mexico City, Mexico), imipramine (10 $\mu \mathrm{mol} / \mathrm{L})$, or DMSO as a vehicle (reagents were purchased from Sigma Chemical Co., St. Louis, MO, USA). Absorbance data were obtained with a microplate photometer (Sunrise Touchscreen, Tecan, Männedorf, Switzerland).

\subsection{Immunochemistry}

HeLa cells and retinoblastoma tissues were seeded on charged glass slides. Retinoblastoma and brain paraffin-embedded tissue sections on a charged slide were boiled for antigen retrieval and processed as previously described [26,30]. The anti-Eag1 antibody was used at a 1:500 dilution overnight at $4{ }^{\circ} \mathrm{C}$. The slides were then incubated with a secondary biotin antibody (Bio SB, Santa Barbara, CA, USA) for $15 \mathrm{~min}$, and the specific staining reaction was completed by incubating the slides in the presence of 3,3'-diaminobenzidine in a buffer reaction solution (Bio SB, Santa Barbara, CA, USA) and observed as brown immunostaining. Tissue sections were counterstained with hematoxylin (Agilent Dako, Santa Clara, CA, USA). The slides were observed using an Olympus IX51 microscope (Olympus Corporation of the Americas, Center Valley, PA, USA), and photographs were taken with an Olympus DP70 camera (Olympus Corporation of the Americas, Center Valley, PA, USA).

\subsection{Western Blotting}

Cells were washed, scraped, and centrifuged, and the obtained pellets were resuspended in a lysis buffer (20 mM MOPS(3-(N-morpholino)propanesulfonic acid)- $\mathrm{NaOH} \mathrm{pH}$ 7.0, $150 \mathrm{mM} \mathrm{NaCl}$, $1 \%$ sodium deoxycholate, $1 \%$ Nonidet P- $40,1 \mathrm{mM}$ EDTA, $0.1 \%$ SDS) supplemented with protease inhibitors. Lysis was completed with the freezing-thawing process; the lysate was then centrifuged, and the supernatant was collected. Forty micrograms of protein was separated using SDS-PAGE $(10 \%)$, transferred to a nitrocellulose membrane, and incubated with the corresponding antibody (anti-Eag1 antibody 1:750 (Novus Biologicals, Littleton, CO, USA), anti-Rb antibody 1:2000 ( Santa Cruz Biotechnology, Dallas, Texas, USA), and anti-actin antibody 1:100,000 (Sigma, Chemical Co., St. Louis, MO, USA). The relative protein quantification was performed with ImageJ software (National Institutes of Health, MD, USA [31].

\subsection{Statistical Analysis}

Analysis of variance followed by the Tukey-Kramer test were used to compare data between different experimental groups using GraphPad Prism software version 5.0 (San Diego, CA, USA). Data analysis from PCR experiments in human tissues was performed with the nonparametric Mann-Whitney test. Comparisons between two or more clinical parameters versus the control were determined with nonparametric ANOVA (Kruskal-Wallis test) and Dunn's test for post hoc analysis. The analysis of the western blot data was performed with Student's $t$-test. The $p$-values $<0.05$ were considered statistically significant in all cases.

\section{Results}

\subsection{RB1 Transfection Decreased Eag1 Expression in HeLa Cells}

First, we evaluated whether $\mathrm{pRb}$ regulated the expression of Eag1 by transfecting HeLa cells with RB1. Real-time PCR experiments showed that RB1-transfected cells exhibited a reduction in Eag1 mRNA expression, while vector-only (pcDNA3)-transfection did not affect Eag1 expression (Figure 1A). Western blot analysis demonstrated an increase in $\mathrm{pRb}$ and the concomitant decrease in Eag1 protein levels in the cells transfected with RB1 (Figure 1B,C). Two Eag1 bands were observed, as expected, because of the reported glycosylated Eag1 form [32]. Immunocytochemistry assays confirmed that transfection with RB1 decreased Eag1 protein levels (Figure 1D,E, brown immunostaining). Next, we investigated the Eag1 expression in human retinoblastoma samples. 
A

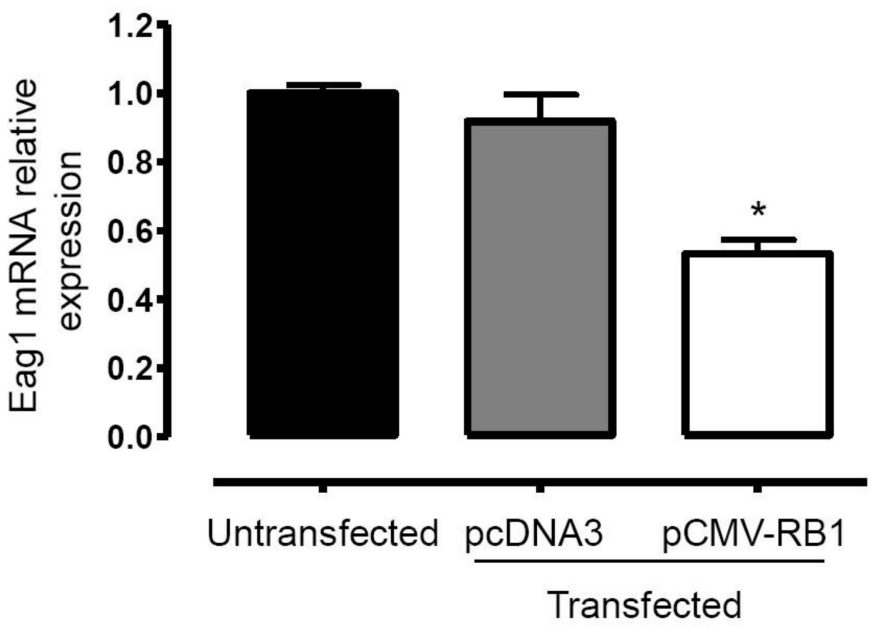

B

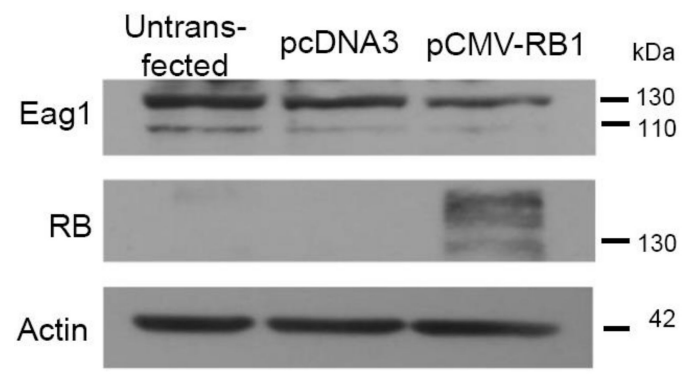

C

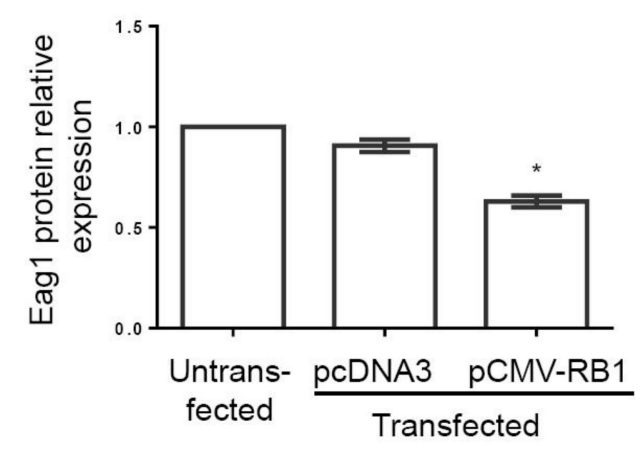

D

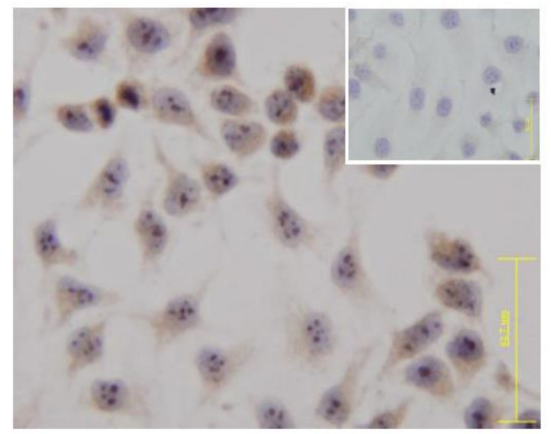

Untransfected

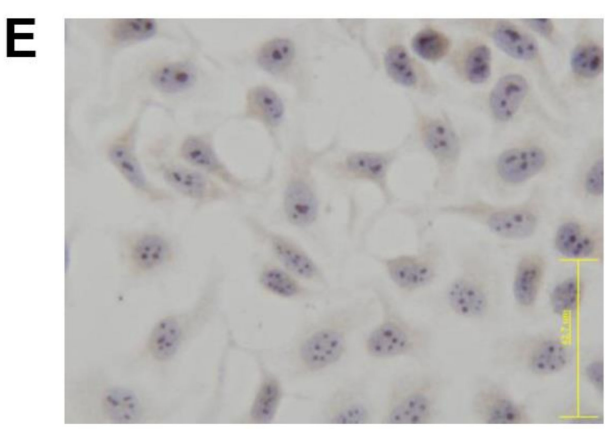

RB1-transfected

Figure 1. Retinoblastoma protein $(\mathrm{pRb})$ down-regulates Ether à-go-go-1 (Eag1) expression in HeLa cells. Relative Eag1 mRNA expression assessed using real-time PCR revealed a significant decrease of Eag1 mRNA expression in cells transfected with RB1. The empty vector (pcDNA3) did not modify Eag1 expression (A). Western blot experiments showed that $\mathrm{pRb}$ transfected cells display lower Eag1 protein levels and higher $\mathrm{pRb}$ expression (B). Quantitative analysis of both Eag1 bands, relative to actin expression (C). Accordingly, untransfected cells displayed clear Eag1 protein expression in immunochemistry assays (brown immunostaining) in the cytoplasm (D), while RB1-transfected cells showed decreased Eag1 protein expression (E). No signal was observed in the absence of the primary antibody (insert, (D)). The graphs show mean \pm s.d., $n=3$ in (A) and $n=5$ in (C). ${ }^{*} p<0.05$ versus untransfected and pcDNA3. Magnification: 400×.

\subsection{Heterogeneous Eag1 mRNA and Protein Expression in Human Retinoblastoma Samples}

To assess whether Eag1 was present in the retinoblastomas, Eag1 mRNA expression was studied in 30 retinoblastoma samples using real-time PCR. Because of the difficulties in obtaining normal retinas 
from children, RNA from a human pediatric normal brain obtained postmortem from a child who died from non-oncologic causes was used as the "control." The Eag1 expression level found in the control tissue was set to a value of 1 to normalize the Eag1 expression in the retinoblastoma samples. While the expression levels of the constitutive genes was very similar among samples, we observed that the Eag1 mRNA level was very heterogeneous in the different samples. In comparison to the control, most of the retinoblastomas had a lower Eag1 mRNA expression, but several samples displayed higher Eag1 levels from 2-7 times that of the control (Figure 2A). Several samples showed Eag1 mRNA levels that were very similar to that of the control. We also used commercially available mRNA from adult normal retina as a "control," obtaining the same type of heterogeneous results, that is, Eag1 mRNA levels were either below, similar, or higher than this control (data not shown). It is important to consider that the best comparison should be performed using normal retinas from children. The samples were then separated into unilateral and bilateral retinoblastoma; however, no statistically significant difference was found between tumor laterality and Eag1 mRNA levels (Figure 2B). In accordance, Eag1 protein expression heterogeneity was also observed in retinoblastoma tissues (Figure 2C-E). When possible, Eag1 mRNA and protein expression were studied in the same sample, although in different tissue sections. Eag1 mRNA levels did not always correlate with Eag1 protein expression. For instance, strong protein channel expression was found in one stage II unilateral retinoblastoma from a boy (Figure 2C, brown immunostaining, zone of normal retina shown), but this sample showed low Eag1 mRNA levels. In another case, weak Eag1 protein expression was observed in the same type of tumor (unilateral retinoblastoma, stage II) but coming from a girl (Figure 2D); in this case, the very low protein expression correlated well with the low Eag1 mRNA level in the same sample. No Eag1 expression was found in a girl with stage II bilateral retinoblastoma (Figure 2E); interestingly, this case exhibited high Eag1 mRNA expression. 
A

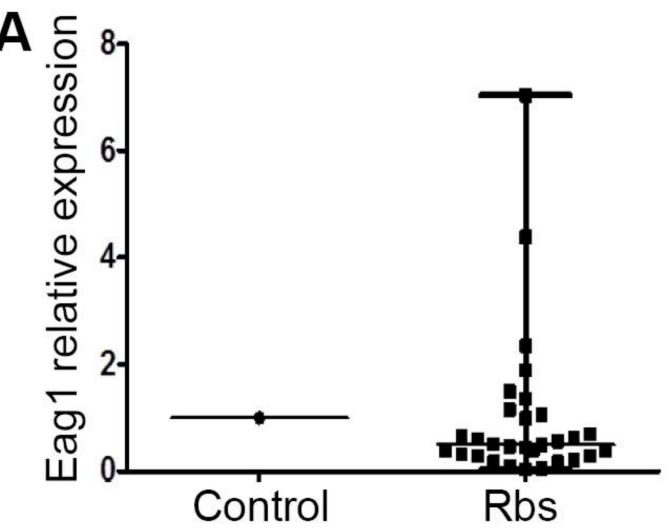

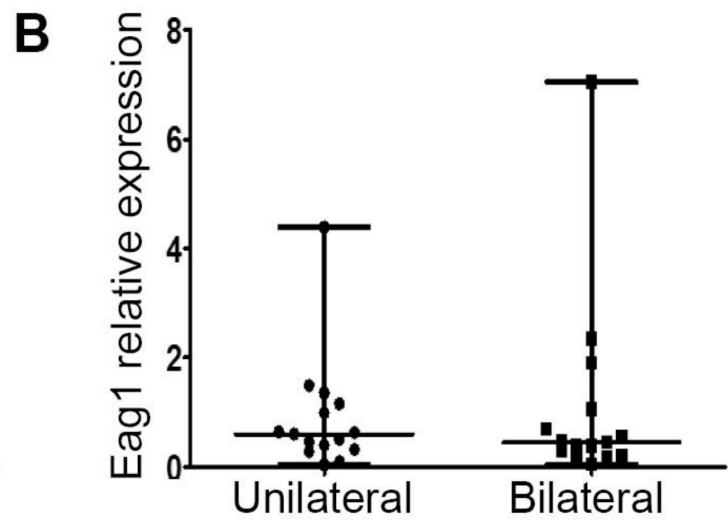

\section{Unilateral retinoblastomas stage II}

C

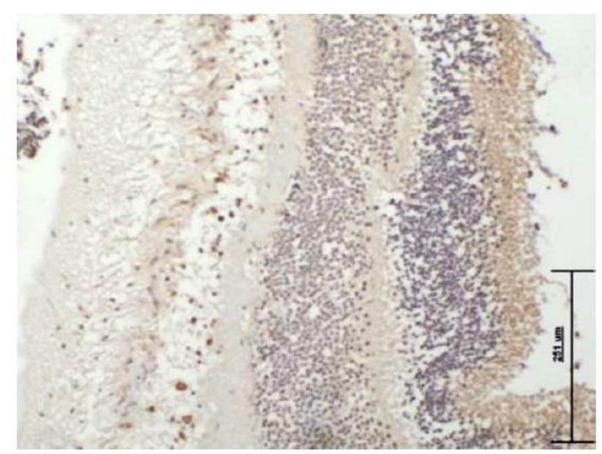

E

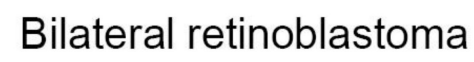
stage II

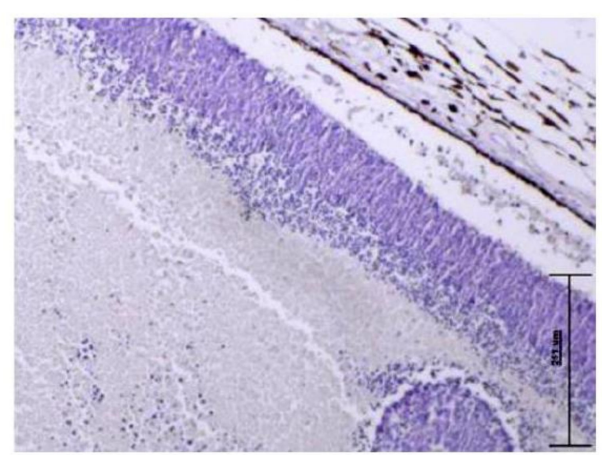

D

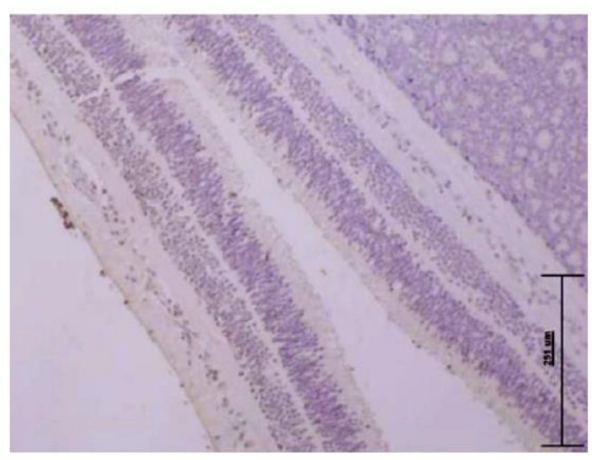

F

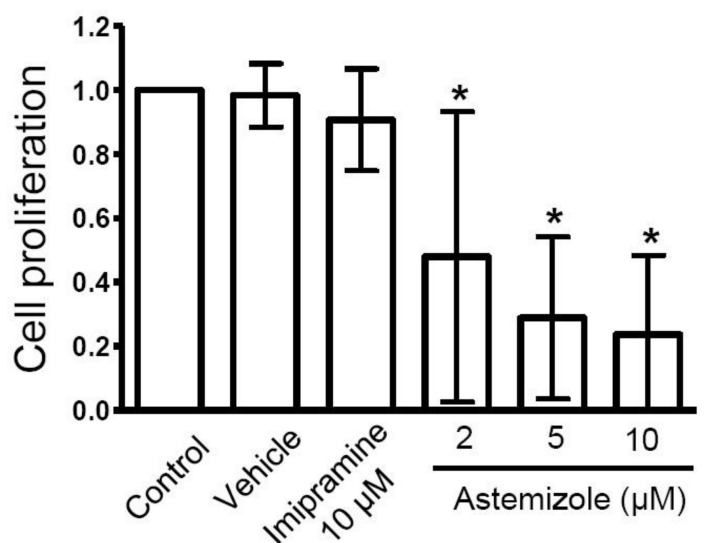

Figure 2. Eag1 was differentially expressed in human retinoblastoma and astemizole inhibited cell proliferation. (A) In comparison with the control (pediatric normal brain obtained postmortem, where the Eag1 mRNA level was set to the value of 1, Eag1 mRNA expression was very heterogeneous between the retinoblastoma samples. Many samples showed a lower expression, while other samples had clearly higher Eag1 mRNA levels. No differences in Eag1 expression versus the control was observed when separating the samples into unilateral $(n=15)$ and bilateral $(n=15)$ tumors $(\mathbf{B})$. Examples of heterogeneous Eag1 protein expression studied using immunohistochemistry in three cases. Positive Eag1 expression in a zone of normal retina from an enucleated retinoblastoma case (C); weak Eag1 expression in retina and in tumor, upper right zone (D) and negative Eag1 expression (E). Magnification: 100x. Astemizole decreased the cell proliferation (assayed by metabolic activity) in retinoblastoma primary cultures $(\mathbf{F})(n=10)$. Each cell proliferation experiment was performed with sextuplicates. Panel (F) shows mean \pm s.d. ${ }^{*} p<0.05$ versus control. 


\subsection{Astemizole Decreased the Cell Proliferation in Primary Retinoblastoma Cultures}

Because many patients do not respond to chemotherapy, it is necessary to find novel therapeutic agents for these patients. Thus, we wondered whether two drugs that are widely used to inhibit Eag1, namely, astemizole and imipramine, might affect the cell proliferation of primary retinoblastoma cultures. The advantage of using these drugs is that they target several proteins involved in cancer, including potassium channels [22-25]. Ten primary retinoblastoma cultures were incubated with either astemizole $(2,5$, or $10 \mu \mathrm{M})$ or imipramine $(10 \mu \mathrm{M})$ for $96 \mathrm{~h}$. While imipramine showed no effect, astemizole decreased the cell proliferation in a concentration-dependent manner (Figure 2F).

\section{Discussion}

New therapeutic approaches for patients with retinoblastoma who do not respond to current treatments or those with advanced disease, as well as molecular insights into the gene expression regulation by retinoblastoma, are needed. Here, we found that $R B 1$ transfection down-regulated the mRNA and protein expression of the oncogenic Eag1 potassium channel in HeLa cells. Experiments to study whether potassium currents and membrane potential are affected by $R B 1$ transfection are warranted. Because of the relevance of Eag1 in cancer, the $\mathrm{pRb}$ regulation of this channel may offer novel approaches that decrease Eag1 expression and subsequently inhibit cancer cell proliferation and tumor development.

We also observed that Eag1 had a heterogeneous distribution in retinoblastoma samples. To our knowledge, this is the first report of Eag1 expression in human retinoblastoma. We used mRNA from a child's brain obtained postmortem to compare Eag1 mRNA expression. Although the best control would be normal child retinas, they are very difficult to obtain. When possible, we studied Eag1 mRNA and protein expression from the same sample. We found a correlation between Eag1 mRNA and protein expression levels in only one out of three cases. Although it is common to find limited correlations between mRNA and protein levels in different systems [33], more studies are needed to determine, for instance, the half-life of Eag1 mRNA and protein in this type of tumor. Unfortunately, the small size of the tumors does not allow for several assays to be performed; however, more quantitative analysis of Eag1 protein expression (for instance, western blot experiments) in retinoblastoma samples is warranted. The different Eag1 mRNA expression levels found between retinoblastoma samples did not correlate with tumor laterality or with other clinical features, such as the tumor stage or sex. This may be explained either by the intertumor heterogeneity or by the mutations in the RB1 gene are diverse, producing truncated versions of $\mathrm{pRb}$ and differentially affecting its ability to associate with the many proteins it is able to bind [6-8]. More studies are needed to determine the potential association of Eag1 expression with prognosis, mutations in RB1, or response to chemotherapy in retinoblastoma. Moreover, the role of Eag1 in retinoblastoma should also be studied, for instance, in animal models. Eag1 knockout mice have been generated [34]. These animals did not show any major abnormalities in the central nervous system level, and it would be very relevant to investigate how sensitive these mice are to develop retinoblastoma. Here, we investigated retinoblastoma tissues from children only; it would also be very important to study retinoblastoma tissues from adults.

We tested the effect of the multitarget Eag1 inhibitors astemizole and imipramine on the cell proliferation of primary retinoblastoma cultures. Although both drugs target Eag1, astemizole also targets other proteins involved in cancer, i.e., Herg1 channels, histamine receptors and ABC transporters [24]. Thus, the effect of astemizole on retinoblastoma cell proliferation may be due to its multitarget properties. More studies are needed to identify the precise molecular mechanisms and targets involved in the inhibition of cell proliferation by astemizole in retinoblastoma cells, as well as the effects of other astemizole concentrations and incubation times, to determine whether astemizole-resistant cells exist. It will also be very important to perform electrophysiological studies to characterize potassium channel activity in primary retinoblastoma cultures. Astemizole inhibits Eag1 mRNA expression in breast and prostate cancer cells [35,36], therefore, it would be very interesting to 
study whether it has the same effect on primary retinoblastoma cultures. The investigation of the effect of other antihistamines on retinoblastoma cell proliferation is also warranted.

\section{Conclusions}

Our results suggest that Eag1 mRNA and protein expression is regulated by $\mathrm{pRb}$ in vitro. Heterogeneous Eag1 mRNA and protein expression is found in human retinoblastoma tissues; to our knowledge, this is the first report of Eag1 expression in human retinoblastoma samples. Our findings also suggest that the multitarget drug astemizole may have clinical relevance in patients with retinoblastoma, for instance, in those who do not respond to current treatments, or those with advanced cases of the disease.

Author Contributions: Conceptualization, M.d.G.C.-L., V.Z.-G., B.E.C.-M., E.G., J.S.-R., M.V.P.-C., M.d.L.C.-M., A.A.-F., and J.C.; methodology (performance of experiments), M.d.G.C.-L., V.Z.-G., B.E.C.-M., E.V., E.G., J.S.-R., M.V.P.-C., M.d.L.C.-M., E.H.-G., and C.S.O.; formal analysis, M.d.G.C.-L., V.Z-G., B.E.C.-M., E.V., E.G., J.S.-R., M.V.P.-C., M.d.L.C.-M., A.A.-F., and J.C.; resources, E.G., J.S.-R., M.V.P.-C., M.d.L.C.-M., Y.E., and J.C.; writing-original draft preparation, M.d.G.C.-L., V.Z.-G., B.E.C.-M., E.G., J.S.-R., and J.C.; writing-review and editing, M.d.G.C.-L., V.Z.-G., B.E.C.-M., E.V., E.G., J.S.-R., M.V.P.-C., M.d.L.C.-M., Y.E., E.H.-G., C.S.O., A.A.-F., and J.C. Current address of C.S.O. is Servicio de Radioterapia, Hospital de Especialidades, Centro Medico Nacional del Bajío, IMSS. Leon, Mexico. All authors have contributed substantially to the work reported. All authors have read and agreed to the published version of the manuscript.

Funding: This research received no external funding.

Conflicts of Interest: The authors declare no conflict of interest.

\section{References}

1. Wong, J.R.; Tucker, M.A.; Kleinerman, R.A.; Devesa, S.S. Retinoblastoma incidence patterns in the US Surveillance, Epidemiology, and End Results program. JAMA Ophthalmol. 2014, 132, 478-483. [CrossRef] [PubMed]

2. Naseripour, M. "Retinoblastoma survival disparity": The expanding horizon in developing countries. Saudi J. Ophthalmol. 2012, 26, 157-161. [CrossRef] [PubMed]

3. Francis, J.H.; Kleinerman, R.A.; Seddon, J.M.; Abramson, D.H. Increased risk of secondary uterine leiomyosarcoma in hereditary retinoblastoma. Gynecol. Oncol. 2012, 124, 254-259. [CrossRef] [PubMed]

4. Kleinerman, R.A.; Schonfeld, S.J.; Tucker, M.A. Sarcomas in hereditary retinoblastoma. Clin. Sarcoma Res. 2012, 2, 15. [CrossRef]

5. Knudson, A.G., Jr. Mutation and cancer: Statistical study of retinoblastoma. Proc. Natl. Acad. Sci. USA 1971, 68, 820-823. [CrossRef]

6. Hirsch, H.A.; Gu, L.; Henry, R.W. The retinoblastoma tumor suppressor protein targets distinct general transcription factors to regulate RNA polymerase III gene expression. Mol. Cell. Biol. 2000, 20, 9182-9191. [CrossRef]

7. Dunaief, J.L.; Strober, B.E.; Guha, S.; Khavari, P.A.; Alin, K.; Luban, J.; Begemann, M.; Crabtree, G.R.; Goff, S.P. The retinoblastoma protein and BRG1 form a complex and cooperate to induce cell cycle arrest. Cell 1994, 79, 119-130. [CrossRef]

8. Zhang, J.; Benavente, C.A.; McEvoy, J.; Flores-Otero, J.; Ding, L.; Chen, X.; Ulyanov, A.; Wu, G.; Wilson, M.; Wang, J.; et al. A novel retinoblastoma therapy from genomic and epigenetic analyses. Nature 2012, 481, 329-334. [CrossRef]

9. Manning, A.L.; Dyson, N.J. RB: Mitotic implications of a tumour suppressor. Nat. Rev. Cancer 2012, 12, 220-226. [CrossRef]

10. Castro-Magdonel, B.E.; Orjuela, M.; Camacho, J.; García-Chéquer, A.J.; Cabrera-Muñoz, M.d.L.; Sadowinski-Pine, S.; Durán-Figueroa, N.; Orozco, M.d.J.; Velazquez, A.C.; Hernández-Ángeles, A.; et al. miRNOME landscape analysis reveals a 30 miRNA core in retinoblastoma. BMC Cancer 2017, 17, 458. [CrossRef]

11. Pardo, L.A.; del Camino, D.; Sanchez, A.; Alves, F.; Bruggemann, A.; Beckh, S.; Stühmer, W. Oncogenic potential of EAG K(+) channels. EMBO J. 1999, 18, 5540-5547. [CrossRef] [PubMed] 
12. Occhiodoro, T.; Bernheim, L.; Liu, J.H.; Bijlenga, P.; Sinnreich, M.; Bader, C.R.; Fischer-Lougheed, J. Cloning of a human ether-a-go-go potassium channel expressed in myoblasts at the onset of fusion. FEBS Lett. 1998, 434, 177-182. [CrossRef]

13. Hemmerlein, B.; Weseloh, R.M.; Mello de Queiroz, F.; Knotgen, H.; Sanchez, A.; Rubio, M.E.; Martin, S.; Schliephacke, T.; Jenke, M.; Heinz Joachim, R.; et al. Overexpression of Eag1 potassium channels in clinical tumours. Mol. Cancer 2006, 5, 41. [CrossRef] [PubMed]

14. Frings, S.; Brull, N.; Dzeja, C.; Angele, A.; Hagen, V.; Kaupp, U.B.; Baumann, A. Characterization of ether-a-go-go channels present in photoreceptors reveals similarity to IKx, a $\mathrm{K}+$ current in rod inner segments. J. Gen. Physiol. 1998, 111, 583-599. [CrossRef]

15. Available online: http://www.proteinatlas.org/ENSG00000143473-KCNH1/tissue (accessed on 29 September 2017).

16. Farias, L.M.; Ocana, D.B.; Diaz, L.; Larrea, F.; Avila-Chavez, E.; Cadena, A.; Hinojosa, L.M.; Lara, G.; Villanueva, L.A.; Vargas, C.; et al. Ether à-go-go potassium channels as human cervical cancer markers. Cancer Res. 2004, 64, 6996-7001. [CrossRef]

17. Ousingsawat, J.; Spitzner, M.; Puntheeranurak, S.; Terracciano, L.; Tornillo, L.; Bubendorf, L.; Kunzelmann, K. Expression of voltage-gated potassium channels in human and mouse colonic carcinoma. Clin. Cancer Res. 2007, 13, 824-831. [CrossRef]

18. De Guadalupe Chavez-Lopez, M.; Hernandez-Gallegos, E.; Vazquez-Sanchez, A.Y.; Gariglio, P.; Camacho, J. Antiproliferative and proapoptotic effects of astemizole on cervical cancer cells. Int. J. Gynecol. Cancer 2014, 24, 824-828. [CrossRef]

19. De Guadalupe Chavez-Lopez, M.; Perez-Carreon, J.I.; Zuniga-Garcia, V.; Diaz-Chavez, J.; Herrera, L.A.; Caro-Sanchez, C.H.; Acuna-Macias, I.; Gariglio, P.; Hernandez-Gallegos, E.; Chiliquinga, A.J.; et al. Astemizole-based anticancer therapy for hepatocellular carcinoma (HCC), and Eag1 channels as potential early-stage markers of HCC. Tumor Biol. 2015, 36, 6149-6158. [CrossRef]

20. Wu, W.; Sanguinetti, M.C. Molecular Basis of Cardiac Delayed Rectifier Potassium Channel Function and Pharmacology. Card. Electrophysiol. Clin. 2016, 8, 275-284. [CrossRef]

21. Fortunato, P.; Pillozzi, S.; Tamburini, A.; Pollazzi, L.; Franchi, A.; La Torre, A.; Arcangeli, A. Irresponsiveness of two retinoblastoma cases to conservative therapy correlates with up- regulation of hERG1 channels and of the VEGF-A pathway. BMC Cancer 2010, 10, 504. [CrossRef]

22. Pardo, L.A.; Stühmer, W. The roles of $\mathrm{K}(+)$ channels in cancer. Nat. Rev. Cancer 2014, 14, 39-48. [CrossRef] [PubMed]

23. Downie, B.R.; Sanchez, A.; Knotgen, H.; Contreras-Jurado, C.; Gymnopoulos, M.; Weber, C.; Stühmer, W.; Pardo, L.A. Eag1 expression interferes with hypoxia homeostasis and induces angiogenesis in tumors. J. Biol. Chem. 2008, 283, 36234-36240. [CrossRef] [PubMed]

24. Garcia-Quiroz, J.; Camacho, J. Astemizole: An old anti-histamine as a new promising anti-cancer drug. Anti-Cancer Agents Med. Chem. 2011, 11, 307-314. [CrossRef] [PubMed]

25. Wang, X.; Chen, Y.; Zhang, Y.; Guo, S.; Mo, L.; An, H. Eag1 Voltage-Dependent Potassium Channels: Structure, Electrophysiological Characteristics, and Function in Cancer. J. Membr. Biol. 2017, 250, 123-132. [CrossRef] [PubMed]

26. Diaz, L.; Ceja-Ochoa, I.; Restrepo-Angulo, I.; Larrea, F.; Avila-Chavez, E.; Garcia-Becerra, R.; Borja-Cacho, E.; Barrera, D.; Ahumada, E.; Gariglio, P.; et al. Estrogens and human papilloma virus oncogenes regulate human ether-a-go-go-1 potassium channel expression. Cancer Res. 2009, 69, 3300-3307. [CrossRef]

27. Lin, H.; Li, Z.; Chen, C.; Luo, X.; Xiao, J.; Dong, D.; Lu, Y.; Yang, B.; Wang, Z. Transcriptional and post-transcriptional mechanisms for oncogenic overexpression of ether a go-go $\mathrm{K}+$ channel. PLoS ONE 2011, 6, e20362. [CrossRef]

28. Urrego, D.; Movsisyan, N.; Ufartes, R.; Pardo, L.A. Periodic expression of Kv10.1 driven by pRb/E2F1 contributes to G2/M progression of cancer and non-transformed cells. Cell Cycle 2016, 15, 799-811. [CrossRef]

29. Orjuela, M.A.; Cabrera-Munoz, L.; Paul, L.; Ramirez-Ortiz, M.A.; Liu, X.; Chen, J.; Mejia-Rodriguez, F.; Medina-Sanson, A.; Diaz-Carreño, S.; Suen, I.H.; et al. Risk of retinoblastoma is associated with a maternal polymorphism in dihydrofolatereductase (DHFR) and prenatal folic acid intake. Cancer 2012, 118, 5912-5919. [CrossRef] 
30. Ortiz, C.S.; Montante-Montes, D.; Saqui-Salces, M.; Hinojosa, L.M.; Gamboa-Dominguez, A.; Hernandez-Gallegos, E.; Martínez-Benítez, B.; Solís-Pancoatl, M.R.; Garcia-Villa, E.; Ramírez, A.; et al. Eag1 potassium channels as markers of cervical dysplasia. Oncol. Rep. 2011, 26, 1377-1383.

31. Davarinejad, H. Quantifications of Western Blots with ImageJ. Available online: www.yorku.ca/yisheng/ Internal/Protocols/ImageJ.pdf (accessed on 20 January 2020).

32. Napp, J.; Monje, F.; Stümer, W.; Pardo, L.A. Glycosylation of Eag1 (Kv10.1) potassium channels: Intracellular trafficking and functional consequences. J. Biol. Chem. 2005, 280, 29506-29512. [CrossRef]

33. Greenbaum, D.; Colangelo, C.; Williams, K.; Gerstein, M. Comparing protein abundance and mRNA expression levels on a genomic scale. Genome Biol. 2003, 4, 117. [CrossRef] [PubMed]

34. Ufartes, R.; Schneider, T.; Mortensen, L.S.; de Juan Romero, C.; Hentrich, K.; Knoetgen, H.; Beilinson, V.; Moebius, W.; Tarabykin, V.; Alves, F.; et al. Behavioural and functional characterization of Kv10.1 (Eag1) knockout mice. Hum. Mol. Genet. 2013, 22, 2247-2262. [CrossRef] [PubMed]

35. García-Quiroz, J.; García-Becerra, R.; Barrera, D.; Santos, N.; Avila, E.; Ordaz-Rosado, D.; Rivas-Suárez, M.; Halhali, A.; Rodríguez, P.; Gamboa-Domínguez, A.; et al. Astemizole Synergizes Calcitriol Antiproliferative Activity by Inhibiting CYP24A1 and Upregulating VDR: A Novel Approach for Breast Cancer Therapy. PLoS ONE 2012, 7, e45063. [CrossRef] [PubMed]

36. Bernal-Ramos, G.; Hernández-Gallegos, E.; Vera, E.; Chávez-López, M.G.; Zúñiga-García, V.; Sánchez-Pérez, Y.; Garrido, E.; Camacho, J. Astemizole inhibits cell proliferation in human prostate tumorigenic cells expressing ether à-go-go-1 potassium channels. Cell. Mol. Biol. 2017, 63, 11-13. [CrossRef]

(C) 2020 by the authors. Licensee MDPI, Basel, Switzerland. This article is an open access article distributed under the terms and conditions of the Creative Commons Attribution (CC BY) license (http://creativecommons.org/licenses/by/4.0/). 